\title{
Reactive oxygen species a double-edged sword for mesothelioma
}

\author{
Serena Benedetti ${ }^{1, *}$, Barbara Nuvoli ${ }^{2, *}$, Simona Catalani ${ }^{1}$, Rossella Galati ${ }^{2}$ \\ ${ }^{1}$ Department of Biomolecular Sciences, University of Urbino "Carlo Bo", Urbino, Italy \\ ${ }^{2}$ Molecular Medicine Area, Regina Elena National Cancer Institute, Rome, Italy \\ *These authors have contributed equally to this work \\ Correspondence to: \\ Rossella Galati, e-mail: galati@ifo.it \\ Keywords: reactive oxygen species, mesothelioma, cell trasformation, cell proliferation, therapy \\ Received: April 20, $2015 \quad$ Accepted: May 29, $2015 \quad$ Published: June 10, 2015
}

\section{ABSTRACT}

It is well known that oxidative stress can lead to chronic inflammation which, in turn, could mediate most chronic diseases including cancer. Oxidants have been implicated in the activity of crocidolite and amosite, the most powerful types of asbestos associated to the occurrence of mesothelioma. Currently rates of mesothelioma are rising and estimates indicate that the incidence of mesothelioma will peak within the next 10-15 years in the western world, while in Japan the peak is predicted not to occur until $\mathbf{4 0}$ years from now. Although the use of asbestos has been banned in many countries around the world, production of and the potentially hazardous exposure to asbestos is still present with locally high incidences of mesothelioma. Today a new man-made material, carbon nanotubes, has arisen as a concern; carbon nanotubes may display 'asbestos-like' pathogenicity with mesothelioma induction potential. Carbon nanotubes resulted in the greatest reactive oxygen species generation. How oxidative stress activates inflammatory pathways leading to the transformation of a normal cell to a tumor cell, to tumor cell survival, proliferation, invasion, angiogenesis, chemoresistance, and radioresistance, is the aim of this review.

\section{INTRODUCTION}

Oxidative stress is defined as an imbalance between the production of free radicals and reactive metabolites, socalled oxidants or reactive oxygen species (ROS), and the ability of a biological system, named antioxidant, to readily detoxify reactive intermediates or repair the resulting damage [1]. ROS are constantly generated under normal conditions as a consequence of aerobic metabolism. The most common ROS types such as superoxide anions $\left(\mathrm{O}_{2}^{-}\right)$, hydrogen peroxide $\left(\mathrm{H}_{2} \mathrm{O}_{2}\right)$, and hydroxyl radicals ( $\mathrm{HO}$ ) are produced by biological reduction of molecular oxygen [2]. The electron transfer to molecular oxygen occurs at the level of the mitochondrial respiratory chain $[3,4]$. Under hypoxic conditions, the mitochondrial respiratory chain also produces nitric oxide (NO), which can generate reactive nitrogen species (RNS) [5].

ROS can react with DNA, proteins, carbohydrates, and lipids in a destructive manner due to their high levels of chemical reactivity. Thus, ROS are considered DNA-damaging agents that increase mutation rates and promote oncogenic transformation, and act as cellular messengers in redox signaling causing disruptions in normal mechanisms of cellular signaling $[6,7]$ (Figure 1). Enzymatic (i.e. superoxide dismutase, catalase, and glutathione peroxidase) and nonenzymatic (i.e. glutathione) antioxidants normally counteract damaging effects of intracellular ROS by either repairing the oxidative damage or directly scavenging oxygen radicals.

In humans, oxidative stress is thought to be involved in the development of cancer [8], and in a wide spectrum of diseases, including chronic inflammation [8-10] (Figure 1). Inflammation is part of the complex biological response to harmful stimuli, such as pathogens, allergens and toxic chemicals. An acute inflammatory response is usually beneficial, and can also be anti-tumorigenic and have a role in tumor suppression [11]. In some disorders, the inflammatory process, which under normal conditions is self-limiting, becomes continuous, and chronic inflammatory diseases might develop subsequently [12]. Epidemiological evidence suggests that 1 out of 4 of all cancers are due to chronic infection or other types of chronic inflammation [13-16]. Chronic inflammation predisposes cells to oncogenic transformation by a variety 

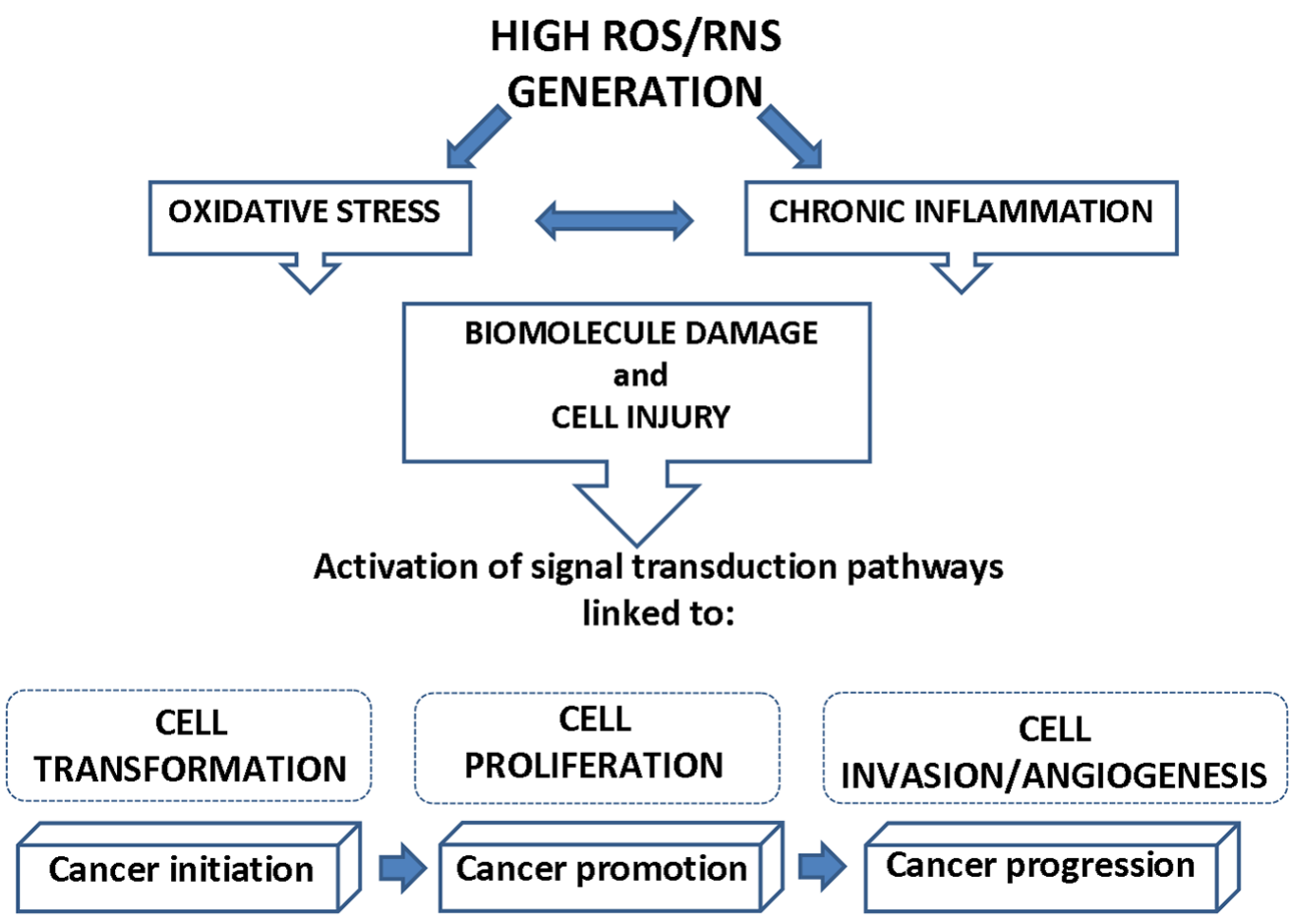

Figure 1: Link between ROS/RNS generation and cancer. High concentration of ROS and RNS, leading to oxidative stress and chronic inflammation, can cause macromolecule damage and cell injury that, in turn, activate signal transduction pathways linked to the progressive phases of carcinogenesis (cell transformation, cell proliferation, cell invasion and angiogenesis).

of mechanisms, including the induction of genomic instability, increasing angiogenesis, altering the genomic epigenetic state, and increasing cell proliferation [17]. Overproduction of reactive oxygen and ROS, aberrant inflammatory cytokine and chemokine expression, increased cyclooxygenase-2 (COX-2), and nuclear factor kappa B (NFkB) expression are just some of the molecular factors that contribute to inflammation-induced carcinogenesis [18]. For example, chronic inflammatory bowel disease is a predisposing factor of colon cancer, chronic $\mathrm{B}$ and $\mathrm{C}$ hepatitis are predisposing factors of hepatocellular carcinoma, and chronic gastritis induced by Helicobacter pylori is a predisposing factor of gastric cancer [19-21]. Similarly, there are studies investigating the link between chronic inflammation associated with long-term asbestos exposure and mesothelioma [22, 23]. Chronic inflammation triggered by asbestos exposure leads to increased production of ROS from inflammatory cells, or alteration of immunocompetent cells and later reduction of tumor immunity $[24,25]$. Free radicals generated from asbestos fibers and/or damages by fibers can alter biological macromolecules including proteins, cell membrane lipids, deoxyribonucleic acid (DNA), and ribonucleic acid (RNA) resulting in the initiation of numerous signal transduction pathways that are linked to inflammation, malignant transformation, proliferation, and apoptosis. How oxidative stress modulates these cellular processes in mesothelioma is the focus of this review, after considering the generation of ROS by asbestos.

\section{Asbestos and oxidants in mesothelioma development}

Malignant mesothelioma (MM) is a tumor arising from mesothelial cells after asbestos exposure.

Asbestos fibers are naturally occurring in rocks and soils, and consist of six distinct types. The amphibole types of asbestos (crocidolite, amosite, anthophyllite, tremolite, and actinolite) are rod-like and more durable in the body than the only serpentine asbestos type, chrysotile [26]. The hazard posed by fibres relates to the mesothelial lining of the pleural cavity and to some extent the peritoneal cavity. Individuals exposed to asbestos demonstrate a wide range of pleural pathologies including pleural effusion (a build up of fluid within the pleural space), pleural fibrosis and pleural mesothelioma [27]. A variable, usually small, proportion of mesotheliomas developing in individuals exposed to asbestos arise in the peritoneal cavity, likely as a result of fibre translocation from the pleural cavity to the peritoneal cavity [28]. It has been postulated that the toxicity of fibres is related to fibre length, bio-persistence, and dose; a hypothesis known as the 'fibre paradigm' [29].

Fibre dimension is important in determining the respirability of the material and its deposition in the respiratory tract. It has been shown that fibre length is also a critical parameter determining its fate in vivo [29]. Indeed, above a certain length, a fibre may not be readily engulfed by cells from the immune system. The retention of long fibres at the stomatal openings on the 
parietal pleura, coupled with frustrated phagocytosis of pleural leukocytes that attempt to ingest them, produce an oxidative stress and a chronic pleural mesothelial inflammatory response which may result in disease [29]. Mesothelial cells internalize the fibers via integrins or other receptors; fibre uptake was found in some studies to be necessary for adverse effects of the fibers such as ROS generation, DNA damage, and apoptosis [30]. Asbestos produces ROS by at least two principal (Figure 2). The first mechanism involves the iron content of the fibre augmenting $\mathrm{HO}$ formation through iron-catalysed reactions. The second mechanism implicates the release of ROS upon activation of inflammatory cells. Asbestos also generates RNS such as nitric oxide (NO) and peroxynitrite ( ONOO) [31]. It has been demonstrated that $\mathrm{H}_{2} \mathrm{O}_{2}, \mathrm{O}_{2}^{--}$and RNS are released from several types of asbestos fibers in cell-free solutions or in cells, especially alveolar or peritoneal macrophages, after phagocytosis of asbestos fibers in vitro or after inhalation [32]. Uptake of asbestos fibers, the leading cause of mesothelioma, results in accumulation of ROS and RNS which act as second messengers of asbestos-mediated carcinogenesis.

\section{Generation of ROS by asbestos}

All types of asbestos have iron cations as an integral component of the crystalline structure, as a substitute cation, or as a surface impurity [33]. The high iron content of asbestos types appears to be critical to the genesis of ROS. The iron associated with asbestos promotes the formation of the highly reactive $\mathrm{HO}$ from $\mathrm{H}_{2} \mathrm{O}_{2}$ with oxidation of ferrous iron $\left(\mathrm{Fe}^{2+}\right)$ to ferric iron $\left(\mathrm{Fe}^{3+}\right)$ (Fenton reaction) [33]. In addition, asbestos can act as a catalyst for the generation of ROS by an iron-mediated HaberWeiss reaction [34]. These highly chemically reactive molecules modify DNA (particularly mitochondrial and telomeric DNA), proteins (including DNA repair enzymes), and lipids. Asbestos-induced cell damage by iron-catalyzed formation of $\operatorname{ROS}[31,35]$, involves DNA strand breaks [36] and oxidant-induced base modifications. 8-Hydroxy-2'-deoxyguanosine (8OHdG), a major product of such oxidative damage [37], causes $\mathrm{G} \rightarrow \mathrm{T}$ and $\mathrm{A} \rightarrow \mathrm{C}$ transversions [38]. These substitutions have been reported as the sites of spontaneous oncogene expression and may be largely responsible for the onset of carcinogenesis and cell proliferation, ultimately leading to cancer manifestation [37-40]. Most of the necessary mutations occur early during cancer development, also resulting in processes such as chronic inflammation, together providing the environment to expand and select malignant clones.

High levels of $\mathrm{G} \rightarrow \mathrm{T}$ transversions in DNA of the omenta (a part of peritoneum), a relevant target tissue for mesothelioma carcinogenesis, were found in rats treated with asbestos [40]. 80HdG levels have been analysed in the peripheral blood cells of asbestos-exposed workers and MM patients and compared with those of age-matched healthy controls [41]. Human exposure to asbestos fibers was found to increase significantly the steady state content of $8 \mathrm{OHdG}$ in lymphocyte DNA of asbestosexposed workers [42]. In addition, individuals who had been exposed to asbestos fibres showed two to four times more DNA double-strand breaks in white blood cells than non-exposed persons [43]. DNA repair mechanisms play a key role in limiting the extent of DNA damage and the accumulation of damaged DNA bases. Although a

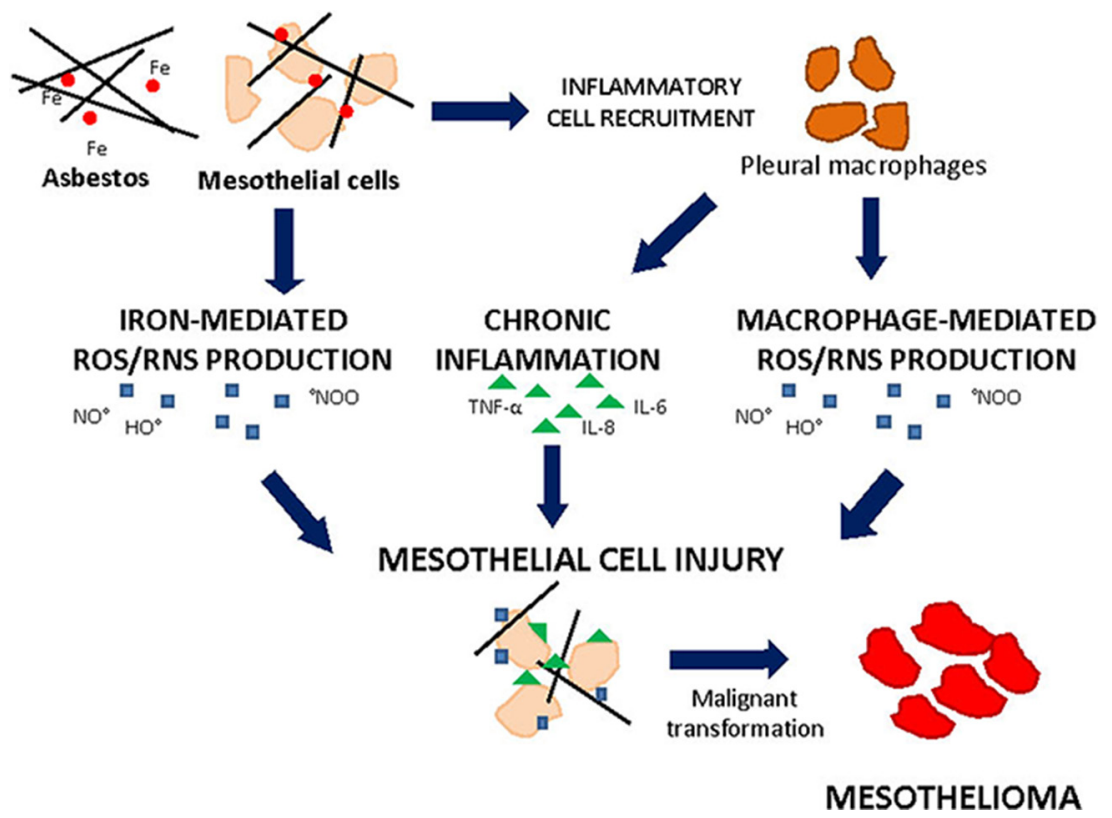

Figure 2: Asbestos-induced cell injury leading to mesothelioma. Mesothelial cells exposed to iron- and macrophage-mediated ROS/RNS production and inflammatory cytokines can cope cell injury and undergo malignant transformation giving rise to mesothelioma. 
significant delay in DNA repair was found in MM patients, no difference in DNA repair rate was observed between asbestos-exposed subjects and unexposed controls [44].

ROS may attack biological macromolecules such as membrane lipids and lead to their peroxidation. Great diversity of aldehydes are formed when lipid hydroperoxides break down in biological systems. Some of these aldehydes are highly reactive and may be considered as second toxic messengers which disseminate in cells and tissues and produce additional damage, including additional lipid peroxidation, oxidative stress, and oxidative attack to DNA [45-47]. Plasma malondialdehyde (MDA) (an indicator of lipid peroxidation) was determined in 97 randomly selected asbestos-exposed workers and in 42 healthy male controls. MDA in asbestos-exposed workers was significantly higher than in controls. Neither age nor smoking was related to MDA levels both in controls and exposed workers [48] .

\section{Generation of RNS by asbestos}

Asbestos has been shown to induce the expression and activity of constitutive or inducible nitric oxide synthase (iNOS) in alveolar macrophages and mesothelial cells [49]. iNOS produces enzymatically from arginine nitric oxide $(\bullet \mathrm{NO})$ which can interact with $\mathrm{O}_{2} \bullet$ to form peroxynitrite $(\bullet \mathrm{ONOO})$, a highly reactive oxidant that attacks a variety of biological targets $[50,51]$ and that may form $\bullet \mathrm{HO}$ as free radical by an iron-independent mechanism $[50,51]$. Interestingly, $\cdot \mathrm{NO}$ also attenuates $\mathrm{H}_{2} \mathrm{O}_{2}$-induced lipid peroxidation and pulmonary artery endothelial cell injury, suggesting that it has antioxidant functions [51,52].

Using an in vitro luciferase model, it was demonstrated that crocidolite activates the iNOS promoter. Moreover, increased steady state levels of iNOS mRNA and production of $\bullet \mathrm{NO} / \bullet \mathrm{ONOO}$ by alveolar macrophages isolated from rats were seen after inhalation of asbestos. This effect was reduced by the NOS inhibitor, NGmonomethyl-L-arginine [53]. Additionally, strong immunoreactivity for nitrotyrosine, a marker of $\bullet \mathrm{ONOO}$ formation, was detected in the lung and pleural mesothelium from chrysotile- and crocidolite-exposed rats [54]. The majority of malignant mesotheliomas express strong iNOS immunoreactivity. In contrast, its expression is infrequently found in non-neoplastic healthy mesothelium [55].

\section{Oxidative stress and mesothelio inflammation}

Asbestos exposure is known to increase the risk of pulmonary pathologies in the form of non-malignant inflammatory diseases, such as pleural plaques, pleural effusions and asbestosis, and malignant diseases, such as mesothelioma and bronchogenic carcinoma. Pleural plaques are produced by the effect of recurrent inflammatory and repair processes occurring for long time periods. Chronic inflammatory episodes may predispose to malignant evolution, as it is known that the majority of MM develops on pleura affected by pleural plaques and not on the normal pleura [56]. Various mechanisms have been advanced for the pathogenesis of asbestos-induced mesothelioma [57]. One proposed mechanism is the oxidative stress concept that highlights how iron within asbestos fibers catalyzes free radical generation and thereby induces oxidative stress and carcinogenesis [32]. Another proposed mechanism is the chronic inflammation by asbestos. Fibre-induced inflammation in the parenchyma reverses both the normal flow of lymph and the normal transpleural pressure, resulting in a net flow of fluid and fibers directly into the pleural space from the underlying parenchyma [58]. This leads to mesothelial and endothelial cell damage, inflammation and accumulation of pleural macrophages. Pleural macrophages undergo frustrated phagocytosis in an attempt to enclose the long fibers. Over time, inflammation becomes chronic and plays an important role in asbestos-induced carcinogenesis that is characterized by persistent release of cytokines and oxidants from macrophages that ultimately lead to further inflammation, fibrosis and genotoxicity in bystander mesothelial cells. Increased pathogenicity of long asbestos fibers depends on the persistent presence of fibers, repeated fibre-induced injury, tissue repair and local inflammation [59]. The mouse peritoneal cavity has been used as a model of direct mesothelial exposure, and much greater inflammatory responses were evidenced in mice exposed to high doses of long fibres than in those exposed to shorter fibres. In vitro systems have also demonstrated the greater potency of long compared to short fibres in assays of proinflammatory and genotoxic activity [60]. Many cytokines and growth factors are shown to be implicated in asbestosinduced MM pathogenesis, including Tumor Necrosis Factor alpha (TNF- $\alpha$ ), Transforming Growth Factor Beta (TGF- $\beta$ ), Platelet-Derived Growth Factor (PDGF), Insulinlike Growth Factor (IGF), interleukin-6 (IL-6), interleukin-8 (IL-8), Vascular Endothelial Growth Factor (VEGF), and Hepatocyte Growth Factor (HGF) [56]. TNF- $\alpha$ is released in response to large accumulations of macrophages undergoing phagocytosis of asbestos. The binding of the released TNF- $\alpha$ to its receptor, TNF-R1, which is also expressed by mesothelial cells and activated by $\mathrm{NF \kappa B}$ pathway, increases the percentage of human mesothelial cells that survive to asbestos exposure [61]. In addition, asbestos exposure causes increased inflammatory responses that include IL$1 \beta$, IL-13, basic Fibroblast Growth Factor (bFGF), VEGF, and granulocyte colony stimulating factor (G-CSF) release, which may be responsible for mesothelioma transformation of these cells [62].

\section{ROS and mesothelioma cell transformation}

Cancer is a multistage process defined by at least three stages: initiation, promotion, and progression. Initiation is defined as a change in genetic material, manifested by DNA damage, mutations, or other DNA heritable changes. These 
genetic alterations may be rendered by increased expression of oncogenes or decreased expression or function of tumor suppressor genes. Initiation alone does not render a cell tumorigenic. Additional signals in "tumor promotion" are required for the expansion of the initiated cell population and subsequent genetic changes. A hallmark of the "tumor promotion" is the modulation of gene expression resulting in increased cell number either through cell division and/or decrease in apoptotic cell death [63]. Following additional chemical insults or through multiple divisions and acquisition of mutations in the preneoplastic focal lesions, the formation of benign and/or malignant neoplasms can occur during the progression stage. Genetic predisposition may play a role in the susceptibility of individuals to certain carcinogens as suggested for mesothelioma found in certain regions of Turkey [64].

Asbestos-induced free radical production results from both direct (e.g. fibre) and indirect (e.g. inflammatory cell recruitment) mechanisms. ROS/RNS elaborated by asbestos may also play a role in tumor promotion, either by stimulating initial mesothelial or epithelial cell damage and subsequent compensatory hyperplasia, or by altering the cell cycle kinetics of initiated mesothelial or epithelial cells [65]. ROS are involved in the link between chronic inflammation and cancer [21]. Indeed, an important characteristic of tumor promoters is their ability to recruit inflammatory cells and to stimulate them to generate ROS [29]. Asbestos and its second messengers, ROS and RNS, cause mutations, altered DNA bases, DNA single-strand, break chromosomal alterations and sister chromatid exchange. Asbestos-induced DNA base pair alterations are probably caused by $\bullet \mathrm{HO}$ and ONOO since these oxidants commonly react with DNA to produce hydroxylated bases or DNA single-strand [66, 67]. As reviewed elsewhere, asbestos promotes $8-\mathrm{OHdG}$ formation in DNA in cell free systems [37, 38]. Ironcatalysed free radicals derived from peroxides or organic hydroperoxides can also augment asbestos-induced DNA damage in cell-free systems [68]. Asbestos-induced DNA damage by iron-derived $\bullet \mathrm{HO}$ can also occur in relevant target cells [69]. A complex profile of somatic genetic changes has been revealed in human MM. These changes implicate a multistep process of tumorigenesis. The occurrence of multiple, recurrent cytogenetic deletions suggests that loss or inactivation of tumor suppressor genes is critical to the development and progression of mesothelioma. Deletions of specific regions in the short (p) arms of chromosomes 1, 3, and 9 and long (q) arms of $6,13,15$, and 22 are repeatedly observed, and loss of a copy of chromosome 22 is the single most consistent numerical change [70]. Relatively little is known about the early changes in the genesis of mesothelioma. Among the known cytogenetic changes, the most frequent is the loss of p16/CDKN2A-p14ARF at 9p21(by homozygous deletion) [71], adversely affecting both Rb and p53 pathways, respectively. NF2 (merlin), a tumor suppressor located at $22 \mathrm{q} 12$, is also frequently altered in mesotheliomas (by an inactivating mutation coupled with allelic loss) [72-73].

\section{ROS and mesothelioma cell survival}

One of the key characteristics of tumor cells is their increased ability to survive compared with normal cells. Survival pathways may be activated by direct interaction of asbestos fibers with receptors on the cell surface and by interaction with integrins, or via elaboration of ROS, and are often up-regulated in MMs, in which they contribute to tumor development, homeostasis, and resistance to chemotherapy [74] (Figure 3).

Epidermal growth factor receptor (EGFR)-linked survival pathways including extracellular signal-regulated kinases (ERKs) 1/2 [75-77], phosphoinositol-3-kinase $(\mathrm{PI} 3 \mathrm{~K}) /$ protein kinase B (AKT) signaling pathways [78], and the downstream mTOR are involved in cell growth and survival, and they are often found to be activated in

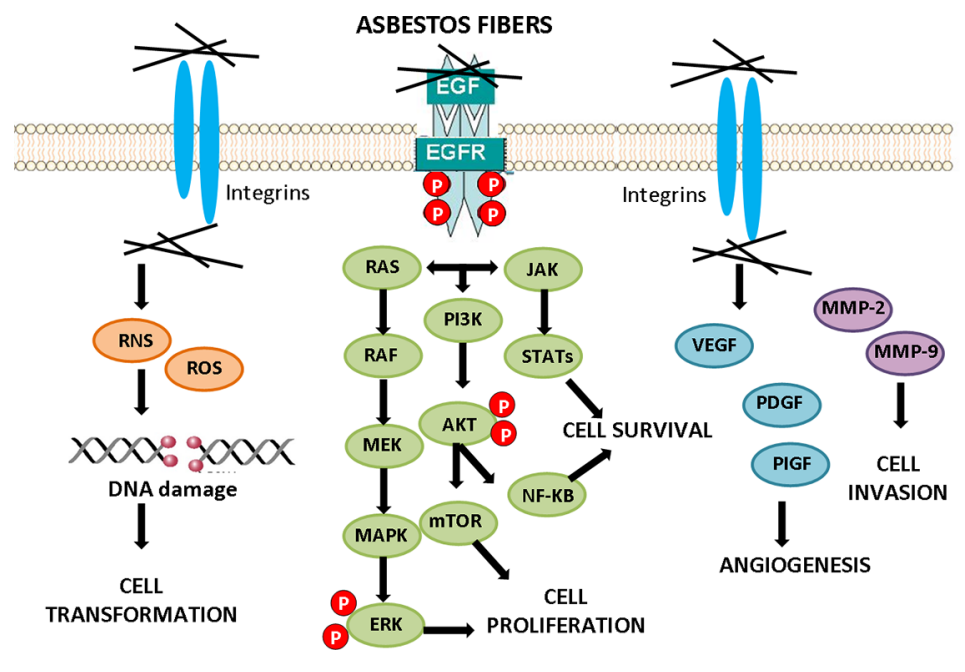

Figure 3: Cell signaling activation by asbestos. Exposure to asbestos fibers leads to the activation of downstream signaling cascades conducing to cell transformation, cancer cell survival and proliferation, angiogenesis and invasion. 
mesothelioma [79]. The activation of the EGFR by asbestos fibers and instigation of these survival cascades may allow a population of asbestos-altered mesothelial cells to be selected and/or expanded in a potentially adverse environment, such as that associated with oxidant-generating asbestos fibers.

The PI3K/Akt signaling pathway is the bestcharacterized pathway in cell survival and its activity can be redox-regulated [80]. Being the signal transduced via phosphorylation, phosphatases are the most important negative regulators. One such phosphatase is the lipid phosphatase PTEN (Phosphatase and Tensin homologue), which can catalyze the opposite reaction of PI3-kinase. PTEN, like other phosphatases, requires reduced cysteines in its active site for activity. Hydrogen peroxide can reversibly inhibit PTEN by oxidation of these key cysteines, resulting in the activation of the PI3-kinase/Akt pathway [81]. Activation of the mammalian target of rapamycin (mTOR) signalling contributes to the pathogenesis of many tumor types [82]. Akt directly phosphorylates and activates mTOR [83]. Akt is also an inhibitor of apoptosis because of its ability to inactivate proapoptotic molecules, including caspase-9 and the Bcl-2 homology domain 3-only protein $\mathrm{Bcl}-\mathrm{XL} / \mathrm{Bcl}-2$-associated death promoter, and by triggering the activity of the transcription factor NF$\kappa \mathrm{B}$. AKT is frequently activated in MM cells. Malignant mesothelioma tumor specimens demonstrate high levels of phosphorylated Akt expression; in addition, a poor survival of malignant pleural mesothelioma (MPM) patients lacking PTEN expression has been observed [78, 84-85]. mTOR signaling pathways has been associated with shortened survival in patients with malignant peritoneal mesothelioma [86]. ROS are both upstream and downstream of mTOR. Activation of the PI3K/TOR pathway increases production of ROS, whereas inhibition of mTOR decreases ROS levels [87]. ROS have been reported to play a role in cell survival by mediating cellular signal transduction pathways. These signaling pathways are involved in the transmission of interor intracellular information, and are critical for supporting tumor cell survival and establishing cell fate. The reduced nicotinammide adenine dinucleotide phosphate oxidase (NOX) family of enzymes, one of the potential sources of ROS production, has been reported to promote tumor cell survival and growth [88]. In mesothelioma cells, higher superoxide production and NOX4 expression were observed as compared to mesothelium [89]. Consequently, ROS potentiate the survival pathways in MM.

\section{ROS and mesothelioma cell proliferation}

Uncontrolled proliferation is a hallmark of cancer cells. ROS and RNS inhibit or promote cell proliferation by modulating the cell signaling pathways that dictate decisions between cell survival, proliferation, and death. In the growth factor-dependent pathways that regulate mitogenesis, numerous positive and negative effectors of signaling are influenced by physiological fluctuations of oxidants, including receptor tyrosine kinases, small GTPases, mitogen-activated protein kinases (MAPK), protein phosphatases, and transcription factors. The same mitogenic pathways that are sensitive to oxidant levels, also directly regulate the expression of cyclin D1, a labile factor required for progression through the G1 phase on the cell cycle. Because the transition from G0 to G1 is the only phase of the cell cycle that is regulated by redox-dependent signaling pathways, expression of cyclin D1 represents a primary regulatory node for the dose-dependent effects of oxidants on the induction of cell growth [90].

Induction of MAPK signaling pathways occurs in response to exposure to asbestos and appears to be related to ROS. The MAPK cascade is characterized by a sequential series of phosphorylation events catalyzed by ERK, c-jun NH2-terminal kinases (JNK) or stressactivated protein kinases (SAPK), and p38 [91], that promote cellular responses, such as proliferation, apoptosis or inflammation [92]. Asbestos fibers selectively induce ERK phosphorylation and activity in mesothelial cells, leading to apoptosis and/or cell proliferation [71, 93-94].

MAPK signaling cascades phosphorylate and activate transcription factors such as activator protein 1 (AP-1) [95]. AP-1 is a family of transcription factors comprised of homo- and heterodimers of the Jun and Fos early response proto-oncogenes. It is a redox-sensitive transcription factor classically associated with the development of cell proliferation and tumor promotion [96]. Asbestos is able to induce AP-1 activation through the activation of MAPK family members, ERK1 and ERK2, in in vitro experiments [97]. Asbestos also induces a dose-dependent activation of NF-kB, a redox sensitive transcription factor $[98,99]$. NF$\mathrm{kB}$ triggers the activation of a number of genes involved in cell proliferation and apoptosis, including cytokines, growth factors, and adhesion molecules as well as proto-oncogenes such as c-myc [100]. Detailed studies to determine how asbestos regulates the transcription factors NF-kB and AP1 , led to the evidence that asbestos-generated ROS could be a possible mechanism [101]. Kinases, such as protein kinase $\mathrm{C}$ (PKC), can also be activated by $\mathrm{H}_{2} \mathrm{O}_{2}$ and redox cycling quinones [102]. PKC is involved in asbestos-induced protooncogene (Fos/Jun) expression in mesothelial cells, and the down-regulation or inhibition of PKC prevents asbestosinduced proto-oncogene expression [103]. Asbestos fibers, either by elaboration of oxidants or interaction with the cell membrane induce mitogenesis and cell proliferation.

\section{ROS and mesothelioma cell invasion}

Human pleural malignant mesothelioma is characterized by aggressive local spreading into the pleura and the surrounding tissues, but it has a low rate of distant metastasis [104]. Malignant tumor invasion of normal tissue involves three independent processes: degradation of the extracellular matrix, cell migration, and proliferation. Matrix metalloproteinases (MMPs) are the main groups of 
enzymes involved in the proteolysis of extracellular matrix proteins, such as collagen, proteoglycans, elastin, laminin, and fibronectin. MMP-2 and MMP-9, key enzymes in the degradation of type IV collagen (the major component of the basement membrane) are abundantly expressed in various malignant tumors and contribute to invasion and metastasis [105].

MMPs have been shown to be elevated in mesothelioma and are known to increase the invasive potential in mesothelioma cells [106]. MMP-2 and MMP-9 expression was reported as a characteristic for pleural malignant mesothelioma, and particularly MMP-2 was suggested as a predictive marker for poor prognosis $[107,108]$. Exposure of cells to $\mathrm{H}_{2} \mathrm{O}_{2}$ increases MMP-2 activation via a receptor tyrosine kinases/PI3-kinase/NF- $\kappa \mathrm{B}$ activation. Oxidative stress may also modulate MMP expression by activation of Ras, or direct activation of the MAPK family members ERK1/2, p38, and JNK, or inactivation of phosphatases that regulate these proteins [109]. In addition, ROS have been implicated in MMP gene expression. Both hydrogen peroxide and nitric oxide donors, as well as the increased expression of iNOS, stimulate the expression of several MMPs [110].

Several studies have reported the involvement of chemokines and chemokine receptors in the invasion and metastasis of various types of tumors. The metastatic potential of chemokines is attributed to their ability to induce the expression of MMPs, which facilitate tumor invasion [111]. Chemokine synthesis is induced in various cells by inflammatory stimuli. Pleural mesothelial cells were observed to produce chemokines on stimulation by inflammatory mediators, asbestos, and ROS [25]. The chemokine CXCL12 (stromal derived factor 1) binding to its receptor CXCR4 may mediate cell adhesion, migration, and proliferation in tumor cells. CXCL12 and CXCR4 were overexpressed in mesothelioma. CXCR4 was found in almost all mesotheliomas (97\%) and CXCL12 in 78\%; another receptor, CXCR7, was only weakly expressed [112].

$\mathrm{H}_{2} \mathrm{O}_{2}$ also influences cell-cell interaction [105]. The CD44 hyaluronic acid receptor, a cell-surface glycoprotein involved in cell-cell interactions, is highly expressed in human mesotheliomas and mediates the association with hyaluronan, a major component of pleural fluid [113]. Mesothelioma cell lines with the highest amount of CD44 receptor show increased proliferation and migration when stimulated with low molecular weight hyaluronic acid. Furthermore, the use of a monoclonal antibody against CD44 inhibits proliferation by $12-40 \%$ and migration by $10-35 \%$ in mesothelioma cell lines [114]. Exemestane, a drug that acts by reduction of CD44, inhibits proliferation and migration in mesothelioma cells [115]. CD44 is influenced by ROS, measured by hydrogen peroxide treatments [116]. Microarray (Affymetrix) data comparing rat pleural mesothelial cells (with and without exposure to crocidolite asbestos) and rat mesotheliomas indicate that
CD44 was increased in mesotheliomas and in mesothelial cells after acute exposure to asbestos [117].

\section{ROS and mesothelioma cell angiogenesis}

Angiogenesis is required for tumors to grow beyond a certain size and to metastasize. The development of a clinically observable tumor requires the neoformation of a vascular network sufficient to sustain tumor growth [118]. A number of cellular stress factors, including hypoxia, nutrient deprivation, and ROS are important stimuli of angiogenic signalling. Asbestos induced angiogenesis surrounding $20-30 \%$ of the lesions after six weekly iniectjons in mice [119]. To develop a stable blood supply for tumor growth, many cells in the tumor microenvironment, including tumor epithelial cells, stromal cells, and immune cells, secrete various proangiogenic factors that stimulate endothelial cell recruitment, proliferation, migration, and tubule formation [120]. Tight regulation of the dynamic equilibrium between proangiogenic and antiangiogenic factors is critical to health, as an imbalance in either direction contributes to a wide range of pathological conditions from atherosclerosis to cancer [121].

A large number of proangiogenic factors and their cognate receptors have been identified, including among the others, Vascular Endothelial Growth Factor (VEGF), Placenta Growth Factor (PlGF), Platelet-Derived Growth Factor (PDGF) and acidic and basic Fibroblast Growth Factors (FGF-1 and -2, respectively). Central to the physiological and pathological regulation of angiogenesis is the VEGF system, its ligands and receptors (VEGFRs). VEGF is the most potent direct-acting angiogenic protein known. It elicits a pronounced angiogenic response in a variety of in vivo models [122]. VEGF has been identified as an important mediator of angiogenesis in malignant mesothelioma. The significant higher levels of VEGF found in the pleural exudates of patients with malignant mesothelioma compared with patients with non malignant pleural disease and the detection of a significant inverse correlation between serum VEGF and malignant mesothelioma patient survival confirm VEGF as an important mediator of angiogenesis [123].

\section{ROS and mesothelioma cell death}

There are three major ways by which a cancer cell can die: apoptosis, necrosis, and autophagy [124-125]. ROS can induce cell death by apoptosis, necrosis, and autophagy [125-127].

\section{ROS and apoptosis}

Resistance to apoptosis may be important both for the initial development and for the subsequent survival of tumors. An initial resistance to apoptosis may be necessary to allow the amplification of an abnormal cell population [128]. Apoptosis is a tightly controlled form of cell death and can be initiated by death receptors (extrinsic pathway) 
or by mitochondria (intrinsic pathway). Both extrinsic and intrinsic pathways of apoptosis depend on ROS [126]. The extrinsic pathway of apoptosis is mediated by death receptors in which ligand-receptor binding initiates protein-protein interactions at cell membranes that, in turn, activate the initiator caspases. Major known receptors include Fas (also called CD95 or APO-1), TNF receptor 1 (TNFR1) and TNF-related apoptosis-inducing ligand (TRAIL) receptor 1 (TRAIL-R1; also called DR4) and TRAIL receptor 2 (TRAIL-R2; also called DR5) $[129,130]$. ROS are required for the ubiquitination and subsequent degradation of the FLICE inhibitory protein to further enhance Fas activation [131]. The intrinsic or mitochondrial apoptotic pathway is characterized by the opening of the permeability transition pore complex on the mitochondrial membrane, which results in cytochrome c release, apoptosome formation, and caspase activation. Opposing effects of pro-apoptotic and anti-apoptotic Bcl2 family proteins are required to open the permeability transition pore. In this context, ROS open the pore by both activating pore-destabilizing proteins (Bcl-2associated $\mathrm{X}$ protein, Bcl-2 homologous antagonist/ killer) and inhibiting pore-stabilizing proteins (Bcl-2 and Bcl-xL) [132]. MM cell lines have been shown to be highly resistant to oxidant (asbestos and ROS) and non oxidant-induced apoptosis, and this resistance is not explained by Bcl-2 [133]. The expression of apoptosisregulating proteins (Bcl-2/Bax and Fas/FasL) and their prognostic significance in asbestos-induced MPM were analyzed in patients with MPM. The findings indicate that Bcl-2 may not be involved in the tumorigenesis of MPM [134]. One explanation for why MM cell lines are more resistant than non-transformed cells is that human MM cell lines have increased Mn-SOD and catalase mRNA levels and activity that render cells more resistant to the cytotoxic effects of an oxidant stress [135]. Notably, cells transfected with Mn-SOD are resistant to apoptosis caused by TNF- $\alpha, \mathrm{H}_{2} \mathrm{O}_{2}$, and irradiation [136] These data suggest that asbestos-induced ROS play a critical role in mediating apoptosis and that increased activity of antioxidant defences, especially Mn-SOD and catalase, accounts in part for the resistance of MM cells to apoptosis. Poly-ADP-ribose polymerase (PARP), a nuclear enzyme, is activated by DNA strand breaks. Prolonged PARP activation can deplete cellular NAD and ATP levels, and thereby augment cell death [137]. PARP may be particularly important since the onset of ROS-induced apoptosis is closely associated with the production of PARP-cleavage products, and reduced PARP activity may impair normal cellular DNA repair mechanisms [138]. PARP activation is also implicated in mediating asbestos-induced mesothelial cell apoptosis, since the PARP inhibitor 3-aminobenzamide (3-ABA) is protective. All this, together with other evidence not discussed here, proves that apoptosis induction in mesothelial cells via ROS represents a mechanism by which mesothelial cells with asbestos-induced DNA damage are deleted. If so, escape from the normal apoptotic pathway may be one important step in the multistep process leading to the development of asbestos-induced neoplasia [139].

\section{ROS and necrosis}

Necrotic cell death has been proposed to involve ROS accumulation [140]. The necrotic pathways, as well as apoptosis, ensure that cells with irreparable damage are eliminated. Necrosis is a form of cell injury that results in the premature death of cells in living tissue. Necrosis is caused by factors external to the cell or tissue, such as infections, toxins, or traumas that result in the unregulated digestion of cell components. Dying cells release the products of cell death into the extracellular space, leading to an anti-inflammatory response in the surrounding tissue [141]. Asbestos causes mesothelial necrotic cell death and promotes an inflammatory response. Macrophages and mesothelial cells release ROS, such as $\mathrm{H}_{2} \mathrm{O}_{2}$ and secrete TNF- $\alpha$, amplifying the inflammatory process. Moreover, ROS cause DNA damage and aneuploidy. TNF- $\alpha$ activates NF- $\kappa \mathrm{B}$, a survival pathway that allows some mesothelial cells undergoing asbestosinduced DNA damage to survive, thereby creating a pool of aneuploid mesothelial cells with the potential to develop into cancer cells. This mechanistic rationale links asbestosinduced mesothelial cell death to the chronic inflammatory reaction that is associated with asbestos carcinogenesis [142].

\section{ROS and autophagy}

Autophagy, a process by which eukaryotic cells degrade and recycle macromolecules and organelles, has an important role in the cellular response to oxidative stress. Autophagy is triggered and regulated by ROS, as revealed by several recent studies $[143,144]$. The outcomes of autophagy vary from survival, by promoting the removal of pathogens, damaged organelles, and proteins, to programmed cell death. Thus, ROS may act as signaling molecules in autophagic cell death, despite they may also act as signaling molecules in survival-prone autophagy [144]. Chrysotile asbestos-induced autophagy is mediated by ROS in A549 human lung epithelial cells [145]; while it does not appear to play a role in mesothelial cells [142].

\section{ROS and mesothelioma therapy}

MM remains a rare and lethal disease, difficulties in MM diagnosis and staging, especially of early disease, have thwarted the development of a universally accepted therapeutic approach. There is no definite standard of care, and only a minority of patients are eligible for any potentially curative therapy. Single modality therapies (surgery, radiotherapy, chemotherapy) have generally failed to significantly prolong patient survival [146]. Surgical resection is the only curative treatment of MPM while other treatments minimally improve 
the response rate and overall survival. The majority of patients diagnosed with MPM are unable to undergo surgical resection because of advanced disease at time of presentation. The only first line chemotherapy regimen approved by the FDA for these patients is cisplatin plus an antifolate, such as pemetrexed or raltitrexed, which improves overall survival from 9 months to 12 months [147, 148]. Radiotherapy may be used for palliative care; however, there is no evidence for routine use of radiation as primary therapy for MPM [149]. For patients with surgically resectable MPM, surgical options include extrapleural pneumonectomy or pleurectomy with decortication which may be combined with intracavitary chemotherapy at the time of resection or systemic chemotherapy and radiotherapy $[150,151]$. Unfortunately, only a small percentage of MPM patients will qualify for multimodality treatment and despite this aggressive therapy, $\mathrm{MM}$ recurrence is frequent. Diffuse malignant peritoneal mesothelioma (DMPM) makes up $15-20 \%$ of MM diagnoses and like MPM, is typically diagnosed at late stage [152]. DMPM is ultimately fatal although advances have been made in therapeutic strategies for surgically resectable diseases. The combination of cytoreductive surgery and hyperthermic intraperitoneal chemotherapy with cisplatin plus doxorubicin or mitomycin-C has been shown to improve overall survival [152]. Patients with inoperable DMPM may undergo systemic chemotherapy with cisplatin and pemetrexed and/or palliation surgery.

\section{ROS-generating drugs and radiotherapy}

ROS production is a mechanism shared by all nonsurgical therapeutic approaches for cancers, including chemotherapy and radiotherapy, due to their implication in triggering cell death; therefore, ROS are also used to kill cancer cells [140]. Based on either side, a number of drugs, agents and approaches have been developed or are under development (Figure 4).
One of the first ROS-generating drugs to be developed was procarbazine. It is oxidised readily in an oxic environment to its azo derivative, generating ROS [154]. A synergistic effect in DNA degradation when procarbazine was combined with radiation was reported. In a study involving 35 patients with mesothelioma treated with either radiation alone or radiation plus procarbazine, none of the 9 patients treated with radiotherapy alone responded, whereas 14 of the 26 patients treated with procarbazine and radiation responded subjectively or objectively. Moreover, the tumour shrinkage in the combined-modality arm was only observed within the radiation field, whereas procarbazine had no effect on the disease outside of the radiation port [155]. Therefore, ROS-generating drugs can be used as a cancer treatment, and perhaps to enhance the antitumour effect of radiation therapy. Radiation therapy involves the administration of ionizing radiation. When cells are ionized, free radicals and ROS are formed. These agents, due to their high reactivity, are likely to attack the covalent bonds of DNA and other cells they encounter, and these reactions typically occur in chains. Enough injury in the cell will result in apoptosis, or programmed cell death. At the same time, if enough DNA is damaged, the cells will be unable to replicate. Thus, when the radiation targets the tumor cells, the affected cells will die or be unable to proliferate, effectively reducing or eliminating the cancer [156]. Though radiation therapy has often resulted in remission of cancer, recurrence is fairly common. Recent research has found that this might be due to cancer stem cells producing higher levels of antioxidant proteins than other cancer cells. The antioxidants capture and disarm ROS before they cause too much damage. Thus, even though it seems that most of the cancer cells have been killed, some cancer stem cells remain and proliferate over time due to the antioxidant defense against ionizing radiation [157]. As cancer cells have elevated ROS generation and are under increased intrinsic oxidative stress, it is conceivable that these malignant cells

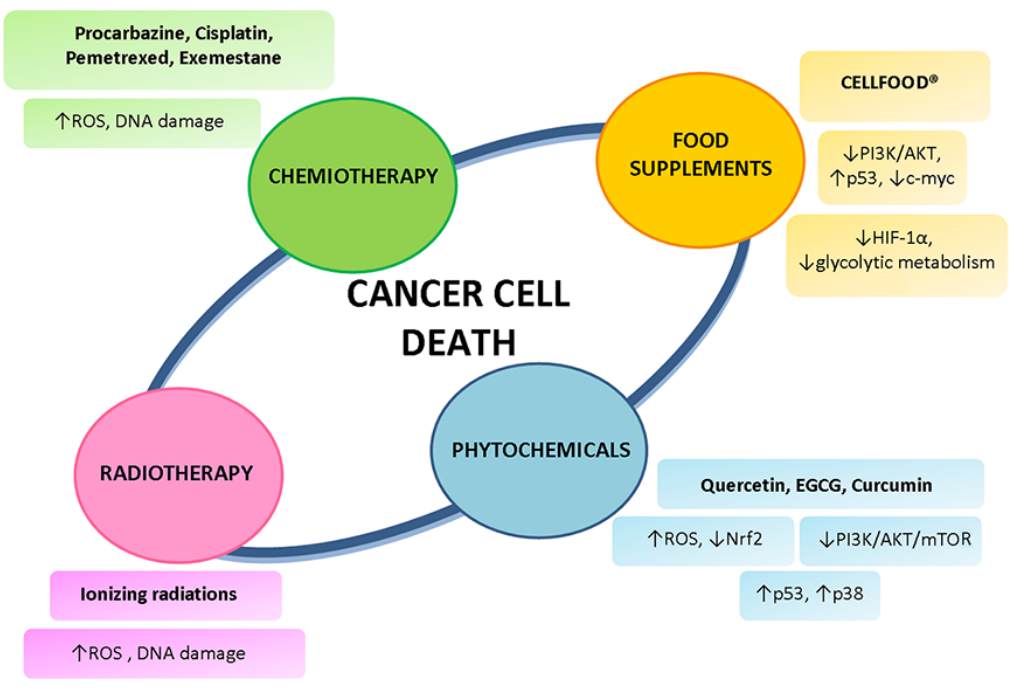

Figure 4: Non-surgical strategies for mesothelioma treatment. Different types of mesothelioma treatment employ not only the standard protocols of chemiotherapy and radiotherapy, but also rely on phytochemicals and food supplements to induce cancer cell death. 
would be more dependent on antioxidants for cell survival and, therefore, more vulnerable to further oxidative insults induced by ROS-generating agents or by compounds that abrogate the key antioxidant systems in cells. As such, manipulating ROS levels by redox modulation seems to be a feasible way to selectively kill cancer cells with less toxicity to normal cells [158]. The idea of inducing preferential cancer cell death by a ROS-mediated mechanism based on the different redox states in normal and malignant cells was proposed a decade ago [159, 160], but its feasibility has only recently gained momentum [161-163]. Cisplatin is one of the most effective and widely used anticancer agents for the treatment of several types of tumors. The cytotoxic effect of cisplatin is thought to be mediated primarily by the generation of nuclear DNA adducts, which, if not repaired, cause cell death as a consequence of DNA replication and transcription blockage [164, 165]. Cisplatin exposure induces a mitochondria-dependent ROS response that significantly contributes to cell killing by enhancing the cytotoxic effect exerted through the formation of DNA damage [166]. In MM cells, cisplatin treatment produced higher ROS levels in MSTO-211H than in NCI-H2452 cells, corresponding to a greater sensitivity of MSTO-211H to the drug. ROS elevation by cisplatin is markedly decreased in the presence of N-Acetyl Cysteine (a ROS scavenger), suggesting that in MM the production of ROS is implicated in the action of cisplatin [167]. Pemetrexed is a first line therapy against mesothelioma. Pemetrexed targets the folate-dependent enzymes thymidylate synthetase (TS), dihydrofolate reductase (DHFR), and glycinamide ribonucleotide formyltransferase (GARFT), all of which are involved in the de novo biosynthesis of purines and pyrimidines, thereby inducing an imbalance in the nucleotide pool and consequent DNA damage [168]. Pemetrexed induces caspase-dependent and -independent apoptosis in human melanoma cells through intracellular ROS accumulation, which in turn promotes DNA damage [169]. In MM cell lines, pemetrexed induced ROS production and caspase-dependent apoptosis [170]. To the best of our knowledge, no previous study has investigated on ROS production in mesotlelioma cells upon pemetrexed and cisplatin combination treatment. Some authors administered a combination of cisplatin, pemetrexed, and valproate (histone deacetylase inhibitor) to three different histological types of mesothelioma (epithelioid, sarcomatoid, and biphasic) cell lines, and found that the number of apoptotic cells increased relative to the first line chemotherapy regimen results (cisplatin + pemetrexed). They also showed that induction of apoptosis resulted from the production of ROS [171]. We recently demonstrated that exemestane, effective in the treatment of $\mathrm{MM}$ in in vivo and in vitro MM experimental models, also acts through ROS production [115, 172, 173].

\section{ROS and natural compounds in mesothelioma treatment}

A large number of dietary phytochemicals has been demonstrated to exhibit anticancer activities by interfering with multiple signaling pathways, resulting in inhibiting survival proteins or activating proapoptotic mediators [174] (Figure 4). In addition, a number of dietary phytochemicals exhibit synergistic effects with conventional chemotherapy and radiotherapy. Of those, resveratrol, a naturally occurring polyphenolic phytoalexin with antioxidant and antiinflammatory effects, has been identified as an effective candidate for overcoming chemoresistance in tumor cells. Many mechanisms of action have been postulated in order to explain the antiproliferative activity of resveratrol including the generation of ROS [175]. In particular, a synergistic anti-proliferative effect occurred in MM cells (MSTO-211H) when resveratrol was combined with the chemotherapeutic drug clofarabine. Such a synergism included simultaneous targeting of multiple biological pathways involving activation of p53 [176], reduction of Nrf2 activity [177], and suppression of Sp1 and PI3kinase/Akt survival proteins [178]. However, despite the large number of preclinical studies dealing with different aspects of the biological effects of resveratrol, its translation to clinics is far from reality due to a variety of challenges [179]. Quercetin is an important dietary flavonoid with diverse biological activities, including antioxidant, antiinflammatory and antitumor properties. Collectively the proapoptotic effects of Quercetin may result from multiple pathways and ROS generation [180]. Experiments on SPC212 and SPC111 mesothelioma cell lines showed that quercetin significantly reduced cell proliferation, altered the cell cycle distribution, and increased the level of Caspase-3 and -9 [181]. Interestingly, the combination of quercetin with cisplatin was found more effective when compared with individual treatment of agents. Other experiments on MSTO-211H mesothelioma cells revealed that quercetin interacted with the transcription factor $\mathrm{Sp} 1$ and significantly suppressed its expression at the protein and mRNA levels. Furthermore, quercetin modulated the levels of Sp1 regulatory genes, such as cyclin D1, myeloid cell leukemia (Mcl)-1 and surviving [182]. Epigallocatechin-3-gallate (EGCG), a natural polyphenol component of green tea, has been extensively studied for its anticarcinogenic effect in a wide variety of cancer cells. Even though EGCG is generally known as an antioxidant, mounting evidence points a role in enhancing ROS release, which in turn inhibits tumor growth [183]. In line with these findings, EGCG was more cytotoxic for MM cells than for normal mesothelial cells, through a mechanism of action based on extracellular $\mathrm{H}_{2} \mathrm{O}_{2}$ production, $\mathrm{Ca}^{2+}$ homeostasis loss, and intracellular ROS increase [184]. At the same time, a negative modulation of mitochondrial oxidative phosphorylation by EGCG leading to growth arrest and apoptosis has been evidenced in MM cells [185]. A series of in vitro tests on MM cells have revealed a synergistic cytotoxicity of EGCG in combination with the conventional tumor drug gemcitabine and with ascorbate (mixture called AND, for Active Nutrients/ Drug) through cell cycle deregulation and apoptosis induction [186, 187]. Interestingly, in vivo experiments 
on a xenograft mouse model for MM, obtained by REN cells injection in immunocompromised mice, showed that AND strongly reduced the size of primary tumor as well as the number and size of metastases [188]. At the cellular level, there was a shift from cell proliferation to apoptosis in the outermost layer of tumor mass, concomitantly with the inactivation of kinases involved in cell growth. Hence, the AND combination has been proposed as a new treatment for MM. Curcumin is a naturally occurring polyphenol in the spice turmeric, which comes from the rhizomes of the herb Curcuma longa. Prior research has identified a broad range of anticarcinogenic potential of curcumin in various cancer types through its antioxidant, anti-inflammation, antiproliferative, antiangiogenic, proapoptotic, and enhancing chemoradiation properties [189]. In human (H2373, H2452, H2461, and H226) and murine (AB12) MM cells, curcumin inhibited cell growth in a dose- and time-dependent manner, while pre-treatment of MM cells with curcumin enhanced cisplatin efficacy [190]. In the same study, curcumin activated the stressactivated p38 kinase, caspases- 9 and -3 , caused elevated levels of proapoptotic proteins Bax, stimulated PARP cleavage, and apoptosis. In addition, oral administration of curcumin inhibited growth of murine MM cell-derived tumors in vivo in part by stimulating apoptosis. However, in the ACC-MESO-1 human MPM cell line, curcumin administration dose-dependently reduced cell viability by inducing autophagy and not apoptosis [191]. Recently, it has been demonstrated that curcumin induces cytotoxic effects on malignant mesothelioma cells (HMESO) through pyroptosis in a process involving ROS production [192]. In addition, curcumin had anti-inflammatory effects by blocking cytokine processing of IL-1 $\beta$ and IL-18 and genes involved in the NF-kB pathway. Overall, these results provide evidence that curcumin warrants further investigation as a therapeutic agent in MM, although future studies must include improved curcumin analogs or enhanced modes of delivery to overcome curcumin's most challenging feature, which is limited bioavailability. Other than protecting biomolecules and cells from oxidative damage [193], evidence has been recently supplied for an anti-cancer activity of Cellfood ${ }^{\mathrm{TM}}$ (CF) [194, 195]. Apoptotic death was observed in CF-treated MSTO-211H. Interestingly, preliminary data indicate that $\mathrm{CF}$, at the doses used to kill MM cells, induces an increase of ROS.

\section{CONCLUSION}

This review implicates the role of ROS in MM pathogenesis. ROS are usually increased in MM cells due to oncogene activation, and are involved in initiation and progression of MM. Ironically, ROS production is a mechanism shared by all non-surgical therapeutic approaches for cancers, including chemotherapy and radiotherapy, due to their implication in triggering cell death, therefore ROS are also used to kill cancer cells.
Because of the double-edged sword property of ROS in determining cell fate, both pro- or anti-oxidant therapies have been proposed for cancer treatment. Based on either side, a number of drugs, agents and approaches have been developed or are under development, some of which have shown clinical promise. This review summarizes the role of ROS in various phases of tumorigenesis and the current understanding on ROS-manipulation strategies in MM treatment.

\section{CONFLICTS OF INTEREST}

The authors declare no conflict of interest.

\section{Author contributions}

SB, BN, SC and RG drafted and wrote the paper. $\mathrm{SC}$ designed the figures. All authors read and approved the final manuscript.

\section{REFERENCES}

1. Durackova Z. Some current insights into oxidative stress. Physiol Res. 2010; 59:459-69.

2. Richter C, Gogvadze V, Laffranchi R, Schlapbach R, Schweizer M, Suter M, Walter P, Yaffee M. Oxidants in mitochondria: from physiology to diseases. Biochim Biophys Acta. 1995; 1271:67-74.

3. Goossens V, De Vos K, Vercammen D, Steemans M, Vancompernolle K, Fiers W, Vandenabeele P, Grooten J. Redox regulation of TNF signalling. Biofactors. 1999; $10: 145-56$

4. Goossens V, Grooten J, De Vos K, Fiers W. Direct evidence for tumor necrosis factor-induced mitochondrial reactive oxygen intermediates and their involvement in cytotoxicity. Proc Natl Acad Sci USA. 1995; 92:8115-19.

5. Poyton RO, Ball KA, Castello PR. Mitochondrial generation of free radicals and hypoxic signalling. Trends Endocrinol Metab. 2009; 20:332-40.

6. Burdon RH, Gill V, Rice-Evans C. Oxidative stress and tumour cell proliferation. Free Radic Res Commun. 1990; 11:65-76.

7. Nicco C, Laurent A, Chereau C, Weill B, Batteux F. Differential modulation of normal and tumor cell proliferation by reactive oxygen species. Biomed Pharmacother. 2005; 59:169-74.

8. Halliwell B. Oxidative stress and cancer: have we moved forward? Biochem J. 401:1-112007; .

9. Valko M, Leibfritz D, Moncol J, Cronin MTD, Mazur M, Telser J. Free radicals and antioxidants in normal physiological functions and human disease. International Journal of Biochemistry \& Cell Biology. 2007; 39:44-84.

10. Pohanka M. Alzheimer's disease and oxidative stress: a review. Current Medicinal Chemistry. 2013; 21:356-64. 
11. Mantovani A, Romero P, Palucka AK, Marincola FM. Tumour immunity: effector response to tumour and role of the microenvironment. Lancet. 2008; 371:771-83.

12. Ferrero-Miliani L, Nielsen OH, Andersen PS, Girardin SE. Chronic inflammation: importance of NOD2 and NALP3 in interleukin-1 beta generation. Clin Exp Immunol. 2007; 147:227-35.

13. Hussain SP, Harris CC. Inflammation and cancer: an ancient link with novel potentials. Int J Cancer. 2007; 121:2373-2380.

14. Bartsch H, Nair J. Chronic inflammation and oxidative stress in the genesis and perpetuation of cancer: role of lipid peroxidation DNA damage and repair. Langenbecks Arch Surg. 2006; 391:499-510.

15. Grivennikov SI, Greten FR, Karin M. Immunity inflammation and cancer. Cell. 2010; 140:883-99.

16. Grivennikov SI, Karin M. Inflammation and oncogenesis: a vicious connection. Curr Opin Genet Dev. 2010; 20:65-71.

17. Coussens LM, Werb Z. Inflammation and cancer. Nature. 2002; 420:860-67.

18. Mantovani A. Molecular pathways linking inflammation and cancer. Curr Mol Med. 2010; 10:369-73.

19. Philip M, Rowley DA, Schreiber H. Inflammation as a tumor promoter in cancer induction Seminars in Cancer Biology. 2004; 14:433-39.

20. Robinson SC, Coussens LM. Soluble mediators of inflammation during tumor development Advances in Cancer Research. 2005; 93:159-187.

21. Federico A, Morgillo F, Tuccillo C, Ciardiello F, Loguercio C. Chronic inflammation and oxidative stress in human carcinogenesis. International Journal of Cancer. 2007; 121:2381-86.

22. Manning CB, Vallyathan V, Mossman BT. Diseases caused by asbestos: mechanisms of injury and disease development. International Immunopharmacology. 2002; 2:191-200.

23. Nuvoli B, Galati R. Cyclooxygenase-2 epidermal growth factor receptor and aromatase signaling in inflammation and mesothelioma. Mol Cancer Ther. 2013; 12:844-52.

24. Kinnula VL, Crapo JD. Superoxide dismutases in the lung and human lung diseases. American Journal of Respiratory and Critical Care Medicine. 2003; 167:1600-19.

25. Matsuzaki H, Maeda M, Lee S, Nishimura Y, KumagaiTakei N, Hayashi H, Yamamoto S, Hatayama T, Kojima Y, Tabata R, Kishimoto T, Hiratsuka J, Otsuki T. Asbestosinduced cellular and molecular alteration of immunocompetent cells and their relationship with chronic inflammation and carcinogenesis. Journal of Biomedicine and Biotechnology. 2012; 2012:492608.

26. Guthrie GD, Mossman BT, Ribbe PH. Health effects of mineral dusts Washington DC: Mineralogical Society of America: 1993.

27. Kane AB. Epidemiology and pathology of asbestos-related diseases. Mineralogy. 1993; 28:347-59.
28. Donaldson K, Borm PJ, Castranova V, Gulumian M. The limits of testing particle-mediated oxidative stress in vitro in predicting diverse pathologies, relevance for testing of nanoparticles. Part Fibre Toxicol. 2009; 6:13.

29. Donaldson K, Murphy FA, Duffin R, Poland CA. Asbestos carbon nanotubes and the pleural mesothelium: a review of the hypothesis regarding the role of long fibre retention in the parietal pleura inflammation and mesothelioma. Part Fibre Toxicol. 2010; 7:5.

30. Liu W, Ernest JD, Broaddus VC. Phagocytosis of crocidolite asbestos induces oxidative stress DNA damage and apoptosis in mesothelial cells. Am J Respir Cell Mol Biol. 2000; 23:371-78.

31. Kamp DW, Graceffa P, Prior WA, Weitzman SA. The role of free radicals in asbestos induced diseases. Free Radic Biol Med. 1992; 12:293-315.

32. Shukla A, Gulumian M, Hei TK, Kamp D, Rahman Q, Mossman BT. Multiple roles of oxidants in the pathogenesis of asbestos-induced diseases. Free Radic Biol Med. 2003; 34:1117-29.

33. Hardy JA, Aust AE. Iron in asbestos chemistry and carcinogenicity. Chem Res. 1995; 95:97-118.

34. Eberhardt MK, Roman-Franco AA, Quiles MR. Asbestos induced decomposition of hydrogen peroxide. Environ Res. 1985; 37:287.

35. Kahlos K, Pitkanen S, Hassinen I, Linnainmaa K, Kinnula VL. Generation of reactive oxygen species by human mesothelioma cells. Br J Cancer. 1999; 80:25-31.

36. Ollikainen T, Linnainmaa K, Kinnula VL. DNA single strand breaks induced by asbestos fibers in human pleural mesothelial cells in vitro. Environ Mol Mutagen. 1999; 33:153-60.

37. Takeuchi T, Morimoto K. Crocidolite asbestos increased 8-hydroxydeoxyguanosine levels in cellular DNA of a human promyelocytic leukaemia cell line HL-60 Carcinogenesis. 1994; 15:635-39.

38. Moriya M. Single-stranded shuttle phagemid for mutagenesis studies in mammalian cells: 8-oxoguanine in DNA induced targeted $\mathrm{GC} \rightarrow$ TA transversions in simian kidney cells. Proc Natl Acad Sci U S A. 1993; 90:1122-26.

39. Loft S, Paulsen HE. Cancer risk and oxidative DNA damage in man. J Mol Med. 1996; 74:297-312.

40. Unfried K, Schurkes C, Abel J. Distinct spectrum of mutations induced by crocidolite asbestos: clue for 8-hydroxydeoxyguanosinedependent mutagenesis in vivo. Cancer Res. 2002; 62:99-104.

41. Amati M, Tomasetti M, Scartozzi M, Mariotti L, Alleva R, Pignotti E, Borghi B, Valentino M, Governa M, Neuzil J, Santarelli L. Profiling tumor-associated markers for early detection of malignant mesothelioma: an epidemiologic study. Cancer Epidemiol Biomarkers Prev. 2008; 17:163-70.

42. Amati M, Tomasetti M, Mariotti L, Tarquini LM, Valentino M, Santarelli L. Assessment of biomarkers in 
asbestos-exposed workers as indicators of cancer risk. Mutat Res. 2008; 655:52-8.

43. Marczynski B, Czuppon AB, Marek W, Reichel G, Baur $\mathrm{X}$. Increased incidence of DNA double-strand breaks and anti-ds DNA antibodies in blood of workers occupationally exposed to asbestos. Hum Exp Toxicol. 1994; 13:3-9.

44. Tomasetti M, Santarelli L. Biomarkers for early detection of malignant mesothelioma: diagnostic and therapeutic application. Cancers. 2010; 14:523-48.

45. Slater TF. Free-radical mechanisms in tissue injury. Biochem J. 1984; 222:1-15.

46. Spitz DR, Malcolm RR, Roberts RJ. Cytotoxicity and metabolism of 4-hydroxy-2-nonenal and 2-nonenal in HO2resistent cell lines Do aldehydic by-products of lipid peroxidation contribute to oxidative stress? Biochem J. 1990; 267:453-59.

47. Esterbauer H, Schaur RJ, Zollner H. Chemistry and biochemistry of 4-hydroxy-nonenal malonaldehyde and related aldehydes. Free Radic Biol Med. 1991; 11:81-128.

48. Kamal AA, Khafif M, Koraah S, Massoud A, Caillard JF. Blood superoxide dismutase and plasma malondialdehyde among workers exposed to asbestos. Am J Ind Med. 1992; 21:353-61.

49. Choe N, Tanaka S, Kagan E. Asbestos fibers and interleukin-1 upregulate the formation of reactive nitrogen species in rat pleural mesothelial cells. Am J Respir Cell Mol Biol. 1998; 19:226-36.

50. Pryor WA, Squadrito GL. The chemistry of peroxynitrite: a product from the reaction of nitric oxide with superoxide. Am J Physiol. 1995; 268:L699-722.

51. Clancy RM, Abramson SB. Nitric oxide: a novel mediator of inflammation. Proc Soc Exp Biol Med. 1995; 37:93-101.

52. Liu G, Cheresh P, Kamp DW. Molecular basis of asbestosinduced lung disease. Annu Rev Pathol. 2013; 248:161-87.

53. Quinlan T, BeruBe K, Hacker M, Taatjes D, Timblin C, Goldberg J, Kimberley P, O’Shaughnessy P, Hemenway D, Torino J, Jimenez L, Mossman B. Mechanisms of asbestos induced nitric oxide production by rat alveolar macrophages in inhalation and in vitro models. Free Radic Biol Med. 1998; 24:778-88.

54. Tanaka S, Choe N, Hemenway D, Zhu S, Matalon S, Kagan E. Asbestos inhalation induces reactive nitrogen species and nitrotyrosine formation in the lungs and pleura of the rat. J Clin Invest. 1998; 102:445-54.

55. Soini Y, Kahlos K, Puhakka A, Lakari E, Säily M, Pääkkö $\mathrm{P}$, Kinnula V. Expression of inducible nitric oxide synthase in healthy pleura and in malignant mesothelioma. $\mathrm{Br} \mathrm{J}$ Cancer. 2000; 83:880-86.

56. Miller J, Shukla A. The Role of inflammation in development and therapy of malignant mesothelioma. American Medical Journal. 2012; 3:240-48.

57. Yang H, Testa JR, Carbone M. Mesothelioma epidemiology carcinogenesis and pathogenesis. Curr Treat Options Oncol. 2008; 9:147-57.
58. Miserocchi G. Physiology and pathophysiology of pleural fluid turnover. Eur Respir J. 1997; 10:219-25.

59. Moalli PA, MacDonald JL, Goodglick LA, Kane AB. Acute injury and regeneration of the mesothelium in response to asbestos fibers. Am J Pathol. 1987; 128:426-45.

60. Donaldson K, Golyasnya N. Cytogenetic and pathogenic effects of long and short amosite asbestos. Journal Of Pathology. 1995; 177:303-07.

61. Yang H, Bocchetta M, Kroczynska B, Elmishad AG, Chen Y, Liu Z, Bubici C, Mossman BT, Pass HI, Testa JR, Franzoso G, Carbone M. TNF-alpha inhibits asbestosinduced cytotoxicity via a NF-kappaB dependent pathway a possible mechanism for asbestos-induced oncogenesis. Proc Natl Acad Sci USA. 2006; 103:10397-402.

62. Shukla A, MacPherson MB, Hillegass J, Ramos-Nino ME, Alexeeva V, Vacek PM, Bond JP, Pass HI, Steele C, Mossman BT. Alterations in gene expression in human mesothelial cells correlate with mineral pathogenicity. Am J Respir Cell Mol Biol. 2009; 41:114-23.

63. Klaunig JE, Kamendulis LM, Hocevar BA. Oxidative stress and oxidative damage in carcinogenesis. Toxicol Pathol. 2010; 38:96-109.

64. Roushdy-Hammady I, Siegel J, Emri S, Testa JR, Carbone M. Genetic-susceptibility factor and malignant mesothelioma in the Cappadocian region of Turkey. Lancet. 2001; 357:444- 45.

65. Heintz NH, Mossman BT. Molecular responses to asbestos: induction of cell proliferation and apoptosis through modulationof redox-dependent cell signaling pathways. In: Craighead JE, Gibbs AR. Asbestos and its diseases Chapter 5. New York: Oxford University Press. 2008 :120-138.

66. Hardy JA, Aust AE. Iron in asbestos chemistry and carcinogenicity. Chem Rev. 1995; 95:97-118.

67. Chao CC, Park SH, Aust AE. Participation of nitric oxide and iron in the oxidation of DNA in asbestos-treated human lung epithelial cells. Arch Biochem Biophys. 1996; 326:152-57.

68. Rahman Q, Mahmood N, Khan SG, Arif JM, Athar M. Mechanism of asbestos-mediated DNA damage: role of heme and heme proteins. Environ Health Perspect. 1997; 105:1109-112.

69. Turver CJ, Brown RC. The role of catalytic iron in asbestos induced lipid peroxidation and DNA-strand breakage in C3H10T 1/2 cells. Br J Cancer. 1987; 56:133-36.

70. Murthy S, Testa J. Asbestos chromosomal deletions and tumor suppressor gene alterations in human malignant mesothelioma. J Cell Physiol. 1999; 180:150-57.

71. Hirao T, Bueno R, Chen C, Gordon G, Heilig E, Kelsey $\mathrm{K}$. Alterations of the p16(INK4) locus in human malignant mesothelial tumors. Carcinogenesis. 2002; 23:1127-30.

72. Bianchi A, Mitsunaga S, Cheng J, Klein WM, Jhanwar SC, Seizinger B, Kley N, Klein-Szanto AJ, Testa JR. High frequency of inactivating mutations in the neurofibromatosis type 2 gene (NF2) in primary malignant mesotheliomas. Proc Natl Acad Sci USA. 1995; 92:10854-58. 
73. Lechner J, Tesfaigzi J, Gerwin B. Oncogenes and tumorsuppressor genes in mesothelioma a synopsis. Environ Health Perspect. 1997; 105:1061-67.

74. Heintz NH, Janssen-Heininger YM, Mossman BT. Asbestos lung cancers and mesotheliomas: from molecular approaches to targeting tumor survival pathways. Am J Respir Cell Mol Biol. 2010; 42:133-39.

75. Lee YJ, Jeong HY, Kim YB, Lee YJ, Won SY, Shim JH, Cho MK, Nam HS, Lee SH. Reactive oxygen species and $\mathrm{PI} 3 \mathrm{~K} /$ Akt signaling play key roles in the induction of Nrf2driven heme oxygenase-1 expression in sulforaphanetreated human mesothelioma MSTO-211H cells. Food Chem Toxicol. 2012; 50:116-23.

76. Jimenez LA, Zanella C, Fung H, Janssen YM, Vacek P, Charland C, Goldberg J, Mossman BT. Role of extracellular signal-regulated protein kinases in apoptosis by asbestos and H2O2. Am J physiol. 1997; 273:L1029-L1035.

77. Zanella CL, Timblin CR, Cummins A, Jung M, Goldberg J, Raabe R, Tritton TR, Mossman BT. Asbestos-induced phosphorylation of epidermal growth factor receptor is linked to c-fos and apoptosis. Am J Physiol. 1999; 277:L684-93.

78. Cacciotti P, Barbone D, Porta C, Altomare DA, Testa JR, Mutti L, Gaudino G. SV40-dependent AKT activity drives mesothelial cell transformation after asbestos exposure. Cancer Res. 2005; 65:5256-62.

79. Wilson SM, Barbone D, Yang TM, Jablons DM, Bueno R, Sugarbaker DJ, et al. mTOR mediates survival signals in malignant mesothelioma grown as tumor fragment spheroids. Am J Respir Cell Mol Biol. 2008; 39:576-83.

80. Clerkin JS, Naughton R, Quiney C, Cotter TG. Mechanisms of ROS modulated cell survival during carcinogenesis. Cancer Lett. 2008; 266:30-36.

81. Leslie NR, Bennett D, Lindsay YE, Stewart H, Gray A, Downes CP. Redox regulation of PI 3-kinase signalling via inactivation of PTEN. Embo J. 2003; 22:5501-10.

82. Guertin DA, Sabatini DM. Defining the role of mTOR in cancer. Cancer Cell. 2007; 12:9-22.

83. Dazert E, Hall MN. mTOR signaling in disease. Curr. Opin. Cell Biol. 2011; 23:744-55.

84. Altomare DA, You H, Xiao GH, Ramos-Nino ME, Skele KL, De Rienzo A, Jhanwar SC, Mossman BT, Kane AB, Testa JR. Human and mouse mesotheliomas exhibit elevated AKT/PKB activity which can be targeted pharmacologically to inhibit tumor cell growth. Oncogene. 2005; 24:6080-89.

85. Opitz I, Soltermann A, Abaecherli M, Hinterberger M, Probst-Hensch N, Stahel R, Moch H, Weder W. PTEN expression is a strong predictor of survival in mesothelioma patients. Eur J Cardiothorac Surg. 2008; 33:502-06.

86. Varghese S, Chen Z, Bartlett DL, Pingpank JF, Libutti SK, Steinberg SM, Wunderlich J, Alexander HR Jr. Activation of the phosphoinositide-3-kinase and mammalian target of rapamycin signaling pathways are associated with shortened survival in patients with malignant peritoneal mesothelioma. Cancer. 2011; 117:361-71.
87. Blagosklonny MV. Aging: ROS or TOR. Cell Cycle. 2008; 7:3344-54.

88. Kamata T. Roles of Nox 1 and other Nox isoforms in cancer development. Cancer Sci. 2009; 100:1382-88.

89. Ranzato E, Biffo S, Burlando B. Selective ascorbate toxicity in malignant mesothelioma: a redox Trojan mechanism. Am J Respir Cell Mol Biol. 2011; 44:108-17.

90. Burch PM, Heintz NH. Redox regulation of cell-cycle re-entry: cyclin D1 as a primary target for the mitogenic effects of reactive oxygen and nitrogen species. Antioxid Redox Signal. 2005; 7:741-51.

91. Karin M. The regulation of AP-1 activity by mitogen activated protein kinases. J of Biol Chem. 1995; 270:16483-86.

92. Ramos-Ninos M, Haegens A, Shukla A, Mossman B. Role of mitogen-activated protein kinases (MAPK) in cell injury and proliferation by environmental particulates. Mol and Cell Bioch. 2002; 234-235:111-18.

93. Zanella C, Posada J, Tritton T, Mossman B. Asbestos causes stimulation of the ERK-1 mitogen-activated protein kinase cascade after phosphorylation of the epidermal growth factor receptor. Cancer Res. 1996; 56:5334-38.

94. Goldberg J, Zanella C, Janssen Y, Timblin C, Jimenez L, Taatjes D, Mossman B. Novel cell imaging approaches show induction of apoptosis and proliferation in mesothelial cells by asbestos. Am J Respir Cell Mol Biol. 1997; 17:265-71.

95. Seger R, Krebs E. The MAPK signaling cascade. FASEB J. 1995; 9:726-35.

96. Su B, Karin M. Mitogen-activated protein kinase cascades and regulation of gene expression. Curr Opin Imm. 1996; 8:402-11.

97. Ding M, Dong Z, Chen F, Pack D, Ma W, Ye J, Shi X, Castranova V, Vallyathan V. Asbestos induces activator protein-1 transactivation in transgenic mice. Cancer Res. 1999; 59:1884-89.

98. Janssen Y, Barchowsky A, Treadwell M, Driscoll K, Mossman B. Asbestos induces nuclear factor kappa B (NF-kappa B) DNA-binding activity and NF-kappa B-dependent gene expression in tracheal epithelial cells. Proc Natl Acad Sci U S A. 1995; 92:8458-62.

99. Janssen Y, Driscoll K, Howard B, Quinlan T, Treadwell M, Barchowsky A, Mossman B. Asbestos causes translocation of p65 protein and increases NF-kappa B DNA binding activity in rat lung epithelial and pleural mesothelial cells. Am J Path. 1997; 151:389-401.

100. Janssen-Heininger Y, Poynter M, Baeuerle P. Recent advances towards understanding redox mechanisms in the activation of nuclear factor kappaB. Free Rad Biol and Med. 2000; 28:1317-27.

101. Faux S, Howden P. Possible role of lipid peroxidation in the induction of NF- B and AP-1 in RFL-6 cells by crocidolite asbestos: Evidence following protection by Vitamin E. Environ Health Perspect. 1997; 105:1127-30. 
102. Kass GE, Duddy SK, Orrenius S. Activation of hepatocyte protein kinase $\mathrm{C}$ by redox-cycling quinones. Biochem J. 1989; 260:499-507.

103. Fung H, Quinlan TR, Janssen YM, Timblin CR, Marsh JP, Heintz NH, Taatjes DJ, Vacek P, Jaken S, Mossman BT. Inhibition of protein kinase $\mathrm{C}$ prevents asbestos-induced c-fos and c-jun proto-oncogene expression in mesothelial cells. Cancer Res. 1997; 57:3101-105.

104. Hughes RS. Malignant pleural mesothelioma. Am J Med Sci. 2005; 329:29-44.

105. Yoon SO, Park SJ, Yoon SY, Yun CH, Chung AS. Sustained production of $\mathrm{H}(2) \mathrm{O}(2)$ activates pro-matrix metalloproteinase-2 through receptor tyrosine kinases/ phosphatidylinositol 3-kinase/NF-kappa B pathway. J Biol Chem. 2002; 277:30271-82.

106. Doi T, Maniwa Y, Tanaka Y, Tane S, Hashimoto S, Ohno Y, Nishio W, Nishimura Y, Ohbayashi C, Okita Y, Hayashi Y, Yoshimura M. MT1-MMP plays an important role in an invasive activity of malignant pleural mesothelioma cell. Exp Mol Pathol. 2011; 90:91-96.

107. Edwards JG, McLaren J, Jones JL, Waller DA, O’Byrne KJ. Matrix metalloproteinases 2 and 9 (gelatinases A and B) expression in malignant mesothelioma and benign pleura. Br J Cancer. 2003; 88:1553-59.

108. Liu Z, Ivanoff A, Klominek J. Expression and activity of matrix metalloproteases in human malignant mesothelioma cell lines. Int J Cancer. 2001; 91:638-43.

109. Nelson KK, Melendez JA. Mitochondrial redox control of matrix metalloproteinases. Free Radic Biol Med. 2004; 37:768-84.

110. Storz P. Reactive oxygen species in tumor progression. Front Biosci. 2005; 10:1881-96.

111. Yuecheng Y, Xiaoyan X. Stromal-cell derived factor-1 regulates epithelial ovarian cancer cell invasion by activating matrix metalloproteinase-9 and matrix metalloproteinase-2. Eur J Cancer Prev. 2007; 16:430-35.

112. Li T, Li H, Wang Y, Harvard C, Tan JL, Au A, Xu Z, Jablons DM, You L. The expression of CXCR4 CXCL12 and CXCR7 in malignant pleural mesothelioma. J Pathol. 2011; 223:519-30.

113. Penno MB, Askin FB, Ma H, Carbone M, Vargas MP, Pass HI. High CD44 expression on human mesotheliomas mediates association with hyaluronan. Cancer J Sci Am. 1995; 1:196-203.

114. Ramos-Nino ME, Blumen SR, Pass H, Mossman BT. Fra-1 governs cell migration via modulation of CD44 expression in human mesotheliomas. Mol Cancer. 2007; $6: 81$.

115. Nuvoli B, Germoni S, Morosetti C, Santoro R, Cortese G, Masi S, Cordone I, Galati R. Exemestane blocks mesothelioma growth through downregulation of cAMPpCREB and CD44 implicating new treatment option in patients affected by this disease. Mol Cancer. 2014; 13:69.

116. Echiburú-Chau C, Roy D, Calaf GM. Metastatic suppressor CD44 is related with oxidative stress in breast cancer cell lines. Int J Oncol. 2011; 39:1481-89.

117. Ramos-Nino ME, Scapoli L, Martinelli M, Land S, Mossman BT. Microarray analysis and RNA silencing link fra-1 to cd44 and c-met expression. Cancer Res. 2003; 63:3539-45.

118. Ribatti D, Nico B, Crivellato E, Roccaro AM, Vacca A. The history of the angiogenic switch concept. Leukemia. 2007; 21:44-52.

119. Branchaud RM, MacDonald JL, Kane AB. Induction of angiogenesis by intraperitoneal injection of asbestos fibers. FASEB J. 1989; 3:1747-52.

120. Folkman J. Angiogenesis in cancer vascular rheumatoid and other disease. Nat Med. 1995; 1:27-31.

121. Plate KH, Breier G, Weich HA, Risau W. Vascular endothelial growth factor is a potential tumour angiogenesis factor in human gliomas in vivo. Nature. 1992; 359:845-48.

122. Kumar-Singh S, Weyler J, Martin MJ, Vermeulen PB, Van Marck E. Angiogenic cytokines in mesothelioma: a study of VEGF FGF-1 and -2 and TGF beta expression. J Pathol. 1999; 189:3-8.

123. Simon HU, Haj-Yehia A, Levi-Schaffer F. Role of reactive oxygen species (ROS) in apoptosis induction. Apoptosis. 2000; 5:415-18.

124. Steller H. Mechanisms and genes of cellular suicide. Science. 1995; 267:1445-49.

125. Wochna A, Niemczyk E, Kurono C, Masaoka M, Kedzior J, Slominska E, Lipinski M, Wakabayashi TA. Possible role of oxidative stress in the switch mechanism of the cell death mode from apoptosis to necrosis - studies on rho0 cells. Mitochondrion. 2007; 7:119-24.

126. Ozben T. Oxidative stress and apoptosis: impact on cancer therapy. J Pharm Sci. 2007; 96:2181-96.

127. Shrivastava A, Kuzontkoski PM, Groopman JE, Prasad A. Cannabidiol induces programmed cell death in breast cancer cells by coordinating the cross-talk between apoptosis and autophagy. Mol Cancer Ther. 2011; 10:1161-72.

128. Thompson CB. Apoptosis in the pathogenesis and treatment of disease. Science. 1995; 267:1456-62.

129. Ashkenazi A, Dixit VM. Apoptosis control by death and decoy receptors. Curr Opin Cell Biol. 1999; 11:255-60.

130. Elmore S. Apoptosis: a review of programmed cell death. Toxicol Pathol. 2007; 35:495-516.

131. Wang X, Zhang J, Xu T. Cyclophosphamide as a potent inhibitor of tumor thioredoxin reductase in vivo. Toxicol Appl Pharmacol. 2007; 218:88-95. 
132. Martindale JL, Holbrook NJ. Cellular response to oxidative stress: signaling for suicide and survival. J Cell Physiol. 2002; 192:1-15.

133. Narasimhan SR, Yang L, Gerwin BI, Broaddus VC. Resistance of pleural mesothelioma cell lines to apoptosis: relation to expression of Bcl-2 and Bax. Am J Physiol. 1998; 275:L165-71.

134. Soini Y, Kinnula V, Kaarteenaho-Wiik R, Kurttila E, Linnainmaa K, Pääkkö P. Apoptosis and expression of apoptosis regulating proteins bcl-2 mcl-1 bcl-Xand bax in malignant mesothelioma. Clin Cancer Res. 1999; $5: 3508-15$.

135. Kahlos K, Anttila S, Asikainen T, Kinnula K, Raivio KO, Mattson K, Linnainmaa K, Kinnula VL. Manganese superoxide dismutase in healthy human pleural mesothelium and in malignant pleural mesothelioma. Am J Respir Cell Mol Biol. 1998; 18:570-80.

136. Manna SK, Zhang HJ, Yan T, Oberley LW, Aggarwal BB. Overexpression of manganese superoxide dismutase suppresses tumor necrosis factor-induced apoptosis and activation of nuclear transcription factor-kappaB and activated protein-1. J Biol Chem. 1998; 273:13245-54.

137. Schraufstatter IU, Hinshaw DB, Hyslop PA, Spragg RG, Cochrane CG. Oxidant injury of cells DNA strand-breaks activate polyadenosine diphosphate-ribose polymerase and lead to depletion of nicotinamide adenine dinucleotide. $\mathrm{J}$ Clin Invest. 1986; 77:1312-20.

138. McGowan AJ, Ruiz-Ruiz MC, Gorman AM, Lopez-Rivas A, Cotter TG. Reactive oxygen intermediate(s) (ROI): common mediator(s) of poly(ADP-ribose)polymerase (PARP)cleavage and apoptosis. FEBS Lett. 392:299-303, 1996.

139. Broaddus VC, Yang L, Scavo LM, Ernst JD, Boylan AM. Asbestos induces apoptosis of human and rabbit pleural mesothelial cells via reactive oxygen species. J Clin Invest. 1996; 98:2050-59.

140. Wang J, Yi J. Cancer cell killing via ROS: to increase or decrease that is the question. Cancer Biol Ther. 2008; 7:1875-84.

141. Proskuryakov SY, Konoplyannikov AG, Gabai VL. Necrosis: a specific form of programmed cell death? Exp Cell Res. 2003; 283:1-16.

142. Yang H, Rivera Z, Jube S, Nasu M, Bertino P, Goparaju C, Franzoso G, Lotze MT, Krausz T, Pass HI, Bianchi ME, Carbone M. Programmed necrosis induced by asbestos in human mesothelial cells causes high-mobility group box 1 protein release and resultant inflammation. Proc Natl Acad Sci U S A. 2010; 107:12611-16.

143. Scherz-Shouval R, Shvets E, Fass E, Shorer H, Gil L, Elazar Z. Reactive oxygen species are essential for autophagy and specifically regulate the activity of Atg4. EMBO J. 2007; 26:1749-60.

144. Scherz-Shouval R, Elazar Z. ROS mitochondria and the regulation of autophagy. Trends Cell Biol. 2007; $17: 422-27$.
145. Lin Z, Liu T, Kamp DW, Wang Y, He H, Zhou X, Li D, Yang L, Zhao B, Liu G. AKT/mTOR and c-Jun N-terminal kinase signaling pathways are required for chrysotile asbestosinduced autophagy. Free Radic Biol Med. 2014; 72:296-307.

146. Ceresoli GL, Gridelli C, Santoro A. Multidisciplinary treatment of malignant pleural mesothelioma. Oncologist. 2007; 12:850-63.

147. Vogelzang NJ, Rusthoven JJ, Symanowski J, Denham C, Kaukel E, Ruffie P, Gatzemeier U, Boyer M, Emri S, Manegold C, Niyikiza C, Paoletti P. Phase III study of pemetrexed in combination with cisplatin versus cisplatin alone in patients with malignant pleural mesothelioma. $\mathrm{J}$ Clin Oncol. 2003; 21:2636-44.

148. Kelly RJ, Sharon E, Hassan R. Chemotherapy and targeted therapies for unresectable malignant mesothelioma. Lung Cancer. 2011; 73:256-63.

149. Price A. What is the role of radiotherapy in malignant pleural mesothelioma. Oncologist. 2011; 16:359-65.

150. Richards WG, Zellos L, Bueno R, Jaklitsch MT, Jänne PA, Chirieac LR, Yeap BY, Dekkers RJ, Hartigan PM, Capalbo L, Sugarbaker DJ. Phase I to II study of pleurectomy/decortication and intraoperative intracavitary hyperthermic cisplatin lavage for mesothelioma. J Clin Oncol. 2006; 24:1561-67.

151. Takigawa N, Kiura K, Kishimoto T. Medical treatment of mesothelioma: anything new? Curr Oncol Rep. 2011; 13:265-71.

152. Turner K, Varghese S, Alexander HR Jr. Current concepts in the evaluation and treatment of patients with diffuse malignant peritoneal mesothelioma. J Natl Compr Canc Netw. 2012; 10:49-57.

153. Baratti D, Kusamura S, Deraco M. Diffuse malignant peritoneal mesothelioma: systematic review of clinical management and biological research. J Surg Oncol. 2011; 103:822-31.

154. Renschler MF. The emerging role of reactive oxygen species in cancer therapy. Eur J Cancer. 2004; 40:1934-40.

155. Falkson G, Falkson HC, Fichardt T. Radiosensitization by procarbazine in the treatment of malignant mesothelioma. Moroson HL, Quintiliani M. Protection and Sensitization. New York: Barnes and Noble1970; :499-501.

156. "Radiation Therapy Principles" American Cancer Society September . 2011; .

157. Diehn M, Cho RW, Lobo NA, Kalisky T, Dorie MJ, Kulp AN, Qian D, Lam JS, Ailles LE, Wong M, Joshua B, Kaplan MJ, Wapnir I, Dirbas FM, Somlo G, Garberoglio C, Paz B, Shen J, Lau SK, Quake SR, Brown JM, Weissman IL, Clarke MF. Association of reactive oxygen species levels and radioresistance in cancer stem cells. Nature. 2009; 458:780-83.

158. Schumacker PT. Reactive oxygen species in cancer cells: live by the sword, die by the sword. Cancer Cell. 2006; 10:175-76.

159. Kong Q, Lillehei KO. Antioxidant inhibitors for cancer therapy. Med Hypotheses. 1998; 51:405-09. 
160. Kong Q, Beel JA, Lillehei KO. A threshold concept for cancer therapy. Med Hypotheses. 2000; 55:29-35.

161. Pelicano H, Carney D, Huang P. ROS stress in cancer cells and therapeutic implications. Drug Resist Updat. 2004; 7:97-110.

162. Cabello CM, Bair WB 3rd, Wondrak GT. Experimental therapeutics: targeting the redox Achilles heel of cancer. Curr Opin Investig Drugs. 2007; 8:1022-37.

163. Fry FH, Jacob C. Sensor/effector drug design with potential relevance to cancer. Curr Pharm Des. 2006; 12:4479-99.

164. Pascoe JM, Roberts JJ. Interactions between mammalian cell DNA and inorganic platinum compounds-I: DNA interstrand cross-linking and cytotoxic properties of platinum(II) compounds. Biochem Pharmacol. 1974; 23:1345-57.

165. Fichtinger-Schepman AMJ, Van der Veer JL, Den Hartog JHJ, Lohman PHM, Reedijk J. Adducts of the antitumor drug cisdiamminedichloroplatinum(II) with DNA: formation identification and quantitation. Biochemistry. 1985; 24:707-13.

166. Marullo R, Werner E, Degtyareva N, Moore B, Altavilla G, Ramalingam SS, Doetsch PW. Cisplatin induces a mitochondrial-ROS response that contributes to cytotoxicity depending on mitochondrial redox status and bioenergetic functions. PLoS One. 2013; 11:e81162.

167. Chen J, Solomides C, Simpkins H. Sensitization of mesothelioma cells to platinum-based chemotherapy by GST knockdown. Biochem Biophys Res Commun. 2014; 447:77-82.

168. Chattopadhyay S, Moran RG, Goldman ID. Pemetrexed: biochemical and cellular pharmacology mechanisms and clinical applications. Mol Cancer Ther. 2007; 6:404-17.

169. Buqué A, Muhialdin JSh, Muñoz A, Calvo B, Carrera S, Aresti U, Sancho A, Rubio I, López-Vivanco G. Molecular mechanism implicated in Pemetrexed-induced apoptosis in human melanoma cells. Mol Cancer. 2012; 11:25.

170. Hwang KE, Kim YS, Hwang YR, Kwon SJ, Park DS, Cha BK, Kim BR, Yoon KH, Jeong ET, Kim HR. Enhanced apoptosis by pemetrexed and simvastatin in malignant mesothelioma and lung cancer cells by reactive oxygen species-dependent mitochondrial dysfunction and Bim induction. Int J Oncol. 2014; 45:1769-77.

171. Vandermeers F, Hubert P, Delvenne P, Mascaux C, Grigoriu B, Burny A, Scherpereel A, Willems L. Valproate in combination with pemetrexed and cisplatin provides additional efficacy to the treatment of malignant mesothelioma. Clin Cancer Res. 2009; 15:2818-28.

172. Stoppoloni D, Salvatori L, Biroccio A, D’Angelo C, Muti P, Verdina A, Sacchi A, Vincenzi B, Baldi A, Galati R. Aromatase inhibitor exemestane has antiproliferative effects on human mesothelioma cells. J Thorac Oncol. 2011; 6:583-91.

173. Nuvoli B, Camera E, Briganti S, Galati R. Modulation of reactive oxygen species and antioxidant defense system are involved in the response of mesothelioma cells to exemestane submitted.
174. González-Vallinas M, González-Castejón M, RodríguezCasado A, Ramírez de Molina A. Dietary phytochemicals in cancer prevention and therapy: a complementary approach with promising perspectives. Nutr Rev. 2013; 71:585-99.

175. Delmas D, Solary E, Latruffe N. Resveratrol a phytochemical inducer of multiple cell death pathways: Apoptosis autophagy and mitotic catastrophe. Curr Med Chem. 2011; 18:1100-21.

176. Lee YJ, Park IS, Lee YJ, Shim JH, Cho MK, Nam HS, Park JW, Oh MH, Lee SH. Resveratrol contributes to chemosensitivity of malignant mesothelioma cells with activation of p53. Food Chem Toxicol. 2014; 63:153-60.

177. Lee YJ, Im JH, Lee DM, Park JS, Won SY, Cho MK, Nam HS, Lee YJ, Lee SH. Synergistic inhibition of mesothelioma cell growth by the combination of clofarabine and resveratrol involves Nrf2 downregulation. BMB Rep. 2012; 45:647-52.

178. Lee YJ, Lee YJ, Im JH, Won SY, Kim YB, Cho MK, Nam HS, Choi YJ, Lee SH. Synergistic anti-cancer effects of resveratrol and chemotherapeutic agent clofarabine against human malignant mesothelioma MSTO-211H cells. Food Chem Toxicol. 2013; 52:61-8.

179. Singh CK, Ndiaye MA, Ahmad N. Resveratrol and cancer: Challenges for clinical translation. Biochim Biophys Acta. 2014; 1852:1178-85.

180. Lee YK, Hwang JT, Kwon DY, Surh YJ, Park OJ. Induction of apoptosis by quercetin is mediated through AMPKalpha1/ASK1/p38 pathway. Cancer Lett. 2010; 292:228-36.

181. Demiroglu-Zergeroglu A, Basara-Cigerim B, Kilic E, Yanikkaya-Demirel G. The investigation of effects of quercetin and its combination with Cisplatin on malignant mesothelioma cells in vitro. J Biomed Biotechnol. 2010; 2010:1-7.

182. Chae JI, Cho JH, Lee KA, Choi NJ, Seo KS, Kim SB, Lee $\mathrm{SH}$, Shim JH. Role of transcription factor Spl in the quercetin-mediated inhibitory effect on human malignant pleural mesothelioma. Int J Mol Med. 2012; 30:835-41.

183. Satoh M, Takemura Y, Hamada H, Sekido Y, Kubota S. EGCG induces human mesothelioma cell death by inducing reactive oxygen species and autophagy. Cancer Cell Int. 2013; 13:19.

184. Ranzato E, Martinotti S, Magnelli V, Murer B, Biffo S, Mutti L, Burlando B. Epigallocatechin-3-gallate induces mesothelioma cell death via $\mathrm{H} 2 \mathrm{O} 2$-dependent T-type Ca2+ channel opening. J Cell Mol Med. 2012; 16:2667-78.

185. Valenti D, de Bari L, Manente GA, Rossi L, Mutti L, Moro L, Vacca RA. Negative modulation of mitochondrial oxidative phosphorylation by epigallocatechin-3 gallate leads to growth arrest and apoptosis in human malignant pleural mesothelioma cells. Biochim Biophys Acta. 2013; 1832:2085-96. 
186. Martinotti S, Ranzato E, Burlando B. In vitro screening of synergistic ascorbate-drug combinations for the treatment of malignant mesothelioma. Toxicol In vitro. 2011; 25:1568-74.

187. Martinotti S, Ranzato E, Parodi M, Vitale M, Burlando B. Combination of ascorbate/epigallocatechin-3-gallate/gemcitabine synergistically induces cell cycle deregulation and apoptosis in mesothelioma cells. Toxicol Appl Pharmacol. 2014; 274:35-41.

188. Volta V, Ranzato E, Martinotti S, Gallo S, Russo MV, Mutti L, Biffo S, Burlando B. Preclinical demonstration of synergistic Active Nutrients/Drug (AND) combination as a potential treatment for malignant pleural mesothelioma. PLoS One. 2013; 8:e58051.

189. Schaffer M, Schaffer PM, Zidan J, Bar Sela G. Curcuma as a functional food in the control of cancer and inflammation. Curr Opin Clin NutrMetab Care. 2011; 14:588-97.

190. Wang Y, Rishi AK, Wu W, Polin L, Sharma S, Levi E, Albelda S, Pass HI, Wali A. Curcumin suppresses growth of mesothelioma cells in vitro and in vivo in part by stimulating apoptosis. Mol Cell Biochem. 2011; 357:83-94.
191. Yamauchi Y, Izumi Y, Asakura K, Hayashi Y, Nomori H. Curcumin induces autophagy in ACC-MESO-1 cells. Phytother Res. 2012; 26:1779-83.

192. Miller JM, Thompson JK, MacPherson MB, Beuschel SL, Westbom CM, Sayan M, Shukla A. Curcumin: a double hit on malignant mesothelioma. Cancer Prev Res (Phila). 2014; 7:330-40.

193. Benedetti S, Catalani S, Palma F, Canestrari F. The antioxidant protection of CELLFOOD against oxidative damage in vitro. Food Chem Toxicol. 2011; 49:2292-98.

194. Catalani S, Carbonaro V, Palma F, Arshakyan M, Galati R, Nuvoli B, Battistelli S, Canestrari F, Benedetti S. Metabolism modifications and apoptosis induction after Cellfood $^{\mathrm{TM}}$ administration to leukemia cell lines. J Exp Clin Cancer Res. 2013; 32:63.

195. Nuvoli B, Santoro R, Catalani S, Battistelli S, Benedetti S, Canestrari F Galati R. CELLFOOD ${ }^{\mathrm{TM}}$ induces apoptosis in human mesothelioma and colorectal cancer cells by modulating p53 c-myc and pAkt signaling pathways. J Exp Clin Cancer Res. 2014; 33:24. 